\title{
Pelaksanaan proses asuhan gizi terstandar (PAGT) terhadap asupan gizi dan kadar glukosa darah pasien diabetes melitus tipe 2
}

Standardized nutrition care process implementation to nutrient intake and blood glucose level of patients with diabetes mellitus type 2

Yunita $^{1}$, Ahmad Husein Asdie ${ }^{2}$, Susetyowati ${ }^{3}$

\begin{abstract}
Background: Food planning is a basis of diabetes mellitus (DM) therapy. Proper diet is essential for effective control of blood glucose level. Diet therapy through the care of nutrition team in hospital can increase nutrient intake of patients in hospital. In 2003 the American Diabetes Association recommended a model of standardized nutrition care process (SNCP). Objective: To find out the effect of SNCP implementation to nutrient intake and blood glucose level of DM type 2 inpatients. Method: The study was a quasi experiment. Nutrient intake variable was measured in post test and blood glucose level variable was pre-post test. Samples were divided into two groups; one group was treated with SNCP and the other with conventional nutrition care. Population of the study consisted of all new patients with DM type 2 diagnosis. Samples were those that met inclusion and exclusion criteria. Data were analyzed by using t-test. Results: Average nutrient intake was found high in the group with SNCP. Nutrient intake comprised energy intake (97.8\%), protein intake (95.1\%), fat intake (95.6\%), and carbohydrate intake (94.9\%). The result of statistical test showed that nutrient intake (energy, protein, fat, carbohydrate) in SNCP was higher than that of conventional nutrition care. Decreasing blood glucose level before and after SNCP intervention was $109.4 \mathrm{mg} / \mathrm{dL}$ wheareas in conventional nutrition care was $105.5 \mathrm{mg} /$ dL. Decreasing blood glucose level of DM type 2 in patients with SNCP was higher than those with conventional nutrition care but statistically was not significant. Conclusion: Nutrient intake (energy, protein, fat and carbohydrate) of DM type 2 in patient with SNCP were higher than those with conventional nutrition care. Decreased blood glucose level of DM type 2 in patients with SNCP was higher than those with conventional nutrition care, which was not stastically significant.
\end{abstract}

KEY WORDS: standardized nutrition care process, nutrient intake, blood glucose

\begin{abstract}
ABSTRAK
Latar belakang: Perencanaan makan merupakan landasan terapi diabetes melitus (DM), diit yang tepat penting untuk mengendalikan kadar glukosa darah dengan efektif. Pemberian terapi diit dengan pendekatan tim asuhan gizi rumah sakit juga dapat meningkatkan asupan zat gizi dan status gizi. Tahun 2003 American Diabetes Association merekomendasikan suatu konsep model standardized nutrition care process (SNCP) atau proses asuhan gizi terstandar (PAGT). Tujuan: Mengetahui pengaruh pelaksanaan PAGT terhadap asupan zat gizi dan kadar glukosa darah pada pasien DM tipe 2. Metode: Jenis penelitian ini adalah eksperimen semu dengan variabel asupan zat gizi adalah pasca uji dan variabel kadar glukosa darah adalah pra-pasca uji. Sampel penelitian diambil yang memenuhi kriteria inklusi dan eksklusi kemudian dibagi 2 kelompok yaitu kelompok PAGT dan kelompok asuhan gizi konvensional. Populasi penelitian adalah semua pasien baru dengan diagnosis diabetes DM tipe2. Data diolah dengan uji t. Hasil: Rerata asupan zat gizi lebih tinggi pada kelompok PAGT yaitu asupan energi sebesar 97,8\%; asupan protein 95,1\%; asupan lemak 95,6\%; dan asupan karbohidrat 94,9\%. Hasil uji statistik menunjukkan bahwa asupan zat gizi (energi, protein, lemak, dan karbohidrat) dengan pelaksanaan PAGT lebih tinggi dibandingkan dengan asuhan gizi konvensional. Penurunan kadar glukosa darah pada kelompok PAGT sebesar 109,4 mg/dL dan kelompok asuhan gizi konvensional sebesar 105,5 mg/dL. Penurunan kadar glukosa darah pada pasien DM tipe 2 dengan PAGT lebih tinggi daripada asuhan gizi konvensional tetapi secara statistik tidak bermakna. Simpulan: Asupan zat gizi (energi, protein, lemak, dan karbohidrat) pada pasien DM tipe 2 dengan pelaksanaan PAGT lebih tinggi dibandingkan dengan asuhan gizi konvensional. Demikian juga penurunan kadar glukosa darah dengan PAGT lebih tinggi daripada asuhan gizi konvensional tetapi secara statistik tidak bermakna.
\end{abstract}

KATA KUNCI: proses asuhan gizi terstandar, asupan zat gizi, kadar glukosa darah

\section{PENDAHULUAN}

Diabetes mellitus (DM) merupakan penyakit degeneratif yang diperkirakan terus meningkat prevalensinya (1). Menurut data Diabetes Atlas 2000

\footnotetext{
Korespondensi: Rumah Sakit Pusat Angkatan Darat (RSPAD) Gatot Soebroto Direktorat Kesehatan Angkatan Darat (Ditkesad), Jl. Abdurrahman Saleh No.24, Jakarta, e-mail: yunita.ita268@gmail.com

Bagian Penyakit Dalam, Rumah Sakit Umum Pusat Dr. Sardjito, Jl. Kesehatan No.1, Yogyakarta 55281

Program Studi Gizi Kesehatan, Fakultas Kedokteran Universitas Gadjah Mada, J1. Farmako, Sekip Utara, Yogyakarta 55281
} 
(International Diabetes Federation), tercantum perkiraan penduduk Indonesia di atas 20 tahun sebesar 125 juta dengan asumsi prevalensi DM sebesar 4,6\% yaitu 5,6 juta pasien diabetes. Berdasarkan pola pertambahan penduduk seperti saat ini, diperkirakan pada tahun 2020 akan ada sejumlah 178 juta penduduk berusia di atas 20 tahun dengan asumsi prevalensi DM sebesar 4,6\% yaitu sebesar 8,2 juta pasien diabetes. Laporan hasil riset kesehatan dasar (Riskesdas) 2007 menyatakan bahwa prevalensi DM di Indonesia sebesar 5,7\% dan di Daerah Khusus Ibukota (DKI) Jakarta sebesar 6,6\%. Proporsi penyebab kematian akibat DM pada kelompok usia 4554 tahun di daerah perkotaan menduduki ranking kedua yaitu $14,7 \%$ (2).

Diabetes mellitus merupakan kumpulan gejala yang timbul pada seseorang disebabkan adanya peningkatan gula darah akibat kekurangan insulin baik absolut maupun relatif(3). Penyandang diabetes akan mengalami defisiensi atau retensi insulin kronik, terganggunya metabolisme karbohidrat, protein, dan lemak sehingga dapat menyebabkan hiperglikemia (peningkatan glukosa darah) (4). Hiperglikemia kronik pada DM berhubungan dengan kerusakan jangka panjang, disfungsi dan atau kegagalan beberapa organ tubuh terutama mata, ginjal, saraf, jantung, dan pembuluh darah (5).

Pilar utama pengelolaan DM meliputi edukasi, terapi gizi medis, latihan jasmani, dan terapi farmakologis. Terapi gizi medis melalui perencanaan makanan merupakan salah satu langkah pertama yang harus dilakukan dalam pengelolaan DM (6). Pengelolaan yang tepat dan berhasil yaitu dengan memberikan dukungan gizi yang tepat melalui pelayanan asuhan gizi yang berkualitas. American Diabetes Association (ADA) merekomendasikan suatu konsep model standardized nutrition care process $(\mathrm{SNCP})$ atau proses asuhan gizi terstandar (PAGT) yang bertujuan agar dietisien dapat memberikan pelayanan asuhan gizi yang berkualitas tinggi, aman, efektif serta hasil yang dicapai dapat diprediksi dan lebih terarah (7). Pasien akan menerima terapi gizi berdasarkan masalah dan penyebab masalah yang berpotensi mengakibatkan malnutrisi selama pasien dirawat di rumah sakit dan berdasarkan evidence based (8). Berdasarkan latar belakang tersebut, maka perlu dilakukan penelitian tentang konsep model pelayanan asuhan gizi yang berkualitas (PAGT) terhadap asupan zat gizi dan kadar glukosa darah pada pasien DM tipe 2 .

\section{BAHAN DAN METODE}

Jenis penelitian ini adalah quasi experimental (eksperimen semu) (9) yang dilakukan paralel pada dua kelompok, yaitu kelompok perlakuan (kelompok PAGT) dan kelompok kontrol (kelompok asuhan gizi konvensional) (10). Penelitian dilakukan di ruang Rawat Inap Penyakit Dalam Rumah Sakit Pusat Angkatan Darat (RSPAD) Gatot Soebroto Direktorat Kesehatan Angkatan Darat (Ditkesad) Jakarta pada bulan Januari-Maret 2012. Populasi penelitian adalah semua pasien baru dengan diagnosis DM tipe 2. Pemilihan subjek penelitian sesuai dengan kriteria inklusi yaitu umur lebih dari atau sama dengan 18 tahun, berisiko malnutrisi atau malnutrisi, dan kesadaran baik sedangkan kriteria eksklusi yaitu hamil, pasien dengan oedema atau ascites, dan pulang atas permintaan responden atau pindah atau dirujuk ke rumah sakit lain atau meninggal.

Besar sampel dihitung berdasarkan rumus pengujian hipotesis pada dua populasi rata-rata (11) dengan standar deviasi $(\sigma)$ asupan zat gizi pasien DM dan nilai rerata perbedaan asupan yang diharapkan $(\mu 1-\mu 2)$ antara kelompok terapi gizi medis (TGM) dan konvensional sebesar 265,3 dan 242,9 (12) serta tingkat kepercayaan

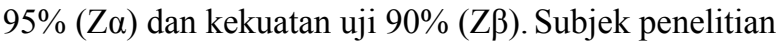
berjumlah 60 orang yang dibagi menjadi dua kelompok yaitu kelompok perlakuan dan kelompok kontrol masing-masing sebanyak 30 orang yang tidak dilakukan matching. Pengambilan sampel dilakukan sesuai dengan kriteria inklusi, eksklusi, dan dikelompokkan berdasarkan tempat yaitu kelompok PAGT dilakukan di lantai 1, 3, $5 \mathrm{a}, 6 \mathrm{a}$ dan kelompok asuhan gizi konvensional dilakukan di lantai 2, 4, 5b, 6 b.

Variabel penelitian ini adalah variabel bebas yaitu jenis asuhan gizi (PAGT dan asuhan gizi konvensional) dan variabel terikat meliputi asupan zat gizi dan kadar glukosa darah. Variabel asupan zat gizi dilihat pasca uji sedangkan variabel glukosa darah dilihat pra-pasca uji. Data asupan zat gizi (energi, protein, lemak, dan karbohidrat) diperoleh dari rerata asupan zat gizi selama subjek dirawat di RS dan dibandingkan dengan kebutuhan gizi subjek. Data kadar 
Pasien masuk

(memenuhi kriteria inklusi dan ekslusi)

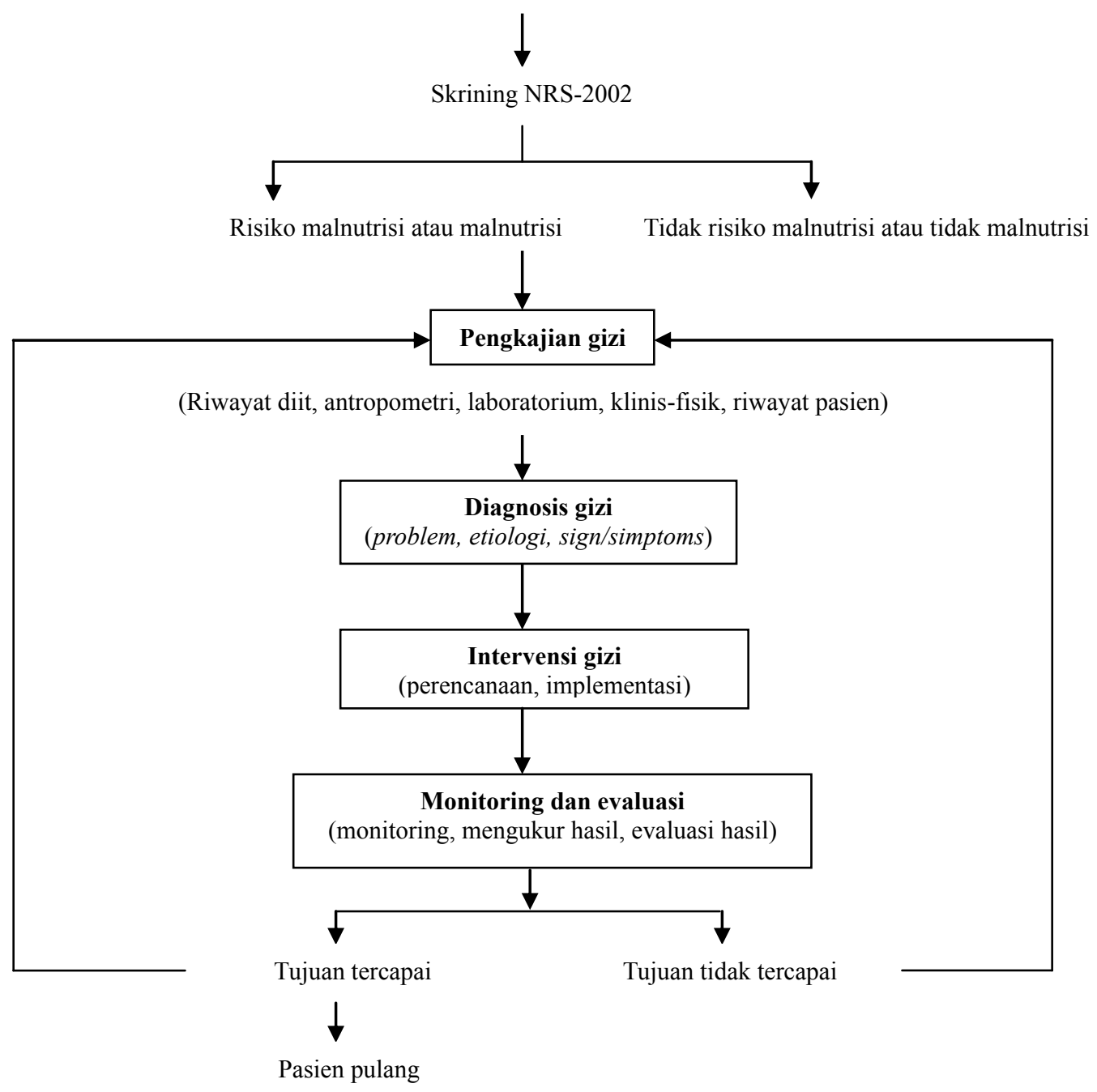

Gambar 1. Alur proses asuhan gizi terstandar (PAGT)

glukosa darah yang diambil adalah data kadar glukosa darah puasa sebelum dan sesudah dilaksanakan asuhan gizi dari hasil pemeriksaan laboratorium yang terlampir di catatan rekam medik subjek.

Asuhan gizi diberikan pada pasien baru yang berisiko malnutrisi atau malnutrisi setelah dilakukan skrining gizi. Jenis skrining gizi yang digunakan adalah skrining Nutritional Risk Screening (NRS-2002). Skrining gizi meliputi kriteria indeks massa tubuh (IMT) kurang dari $20,5 \mathrm{~kg} / \mathrm{m}^{2}$, berat badan hilang dalam 3 bulan, asupan turun pada minggu terakhir, menderita penyakit berat (pasien dengan penyakit penyerta atau adanya komplikasi), dan gangguan status gizi. Apabila skor skrining gizi kurang dari atau sama dengan 3 maka dikategorikan berisiko malnutrisi atau malnutrisi dan setelah sesuai kriteria inklusi dan eksklusi, maka pasien dijadikan subjek penelitian kemudian diberikan asuhan gizi.

Tahapan kegiatan pada kelompok PAGT meliputi pengkajian gizi, diagnosis gizi, intervensi, dan monitoring evaluasi sedangkan kelompok asuhan gizi konvensional meliputi pengkajian gizi, intervensi, dan monitoring evaluasi. Perbedaan pada kedua kelompok terdapat pada tahapan diagnosis gizi, yaitu intervensi pada kelompok PAGT dilakukan berdasarkan diagnosis gizi sedangkan pada kelompok asuhan gizi konvensional intervensi 


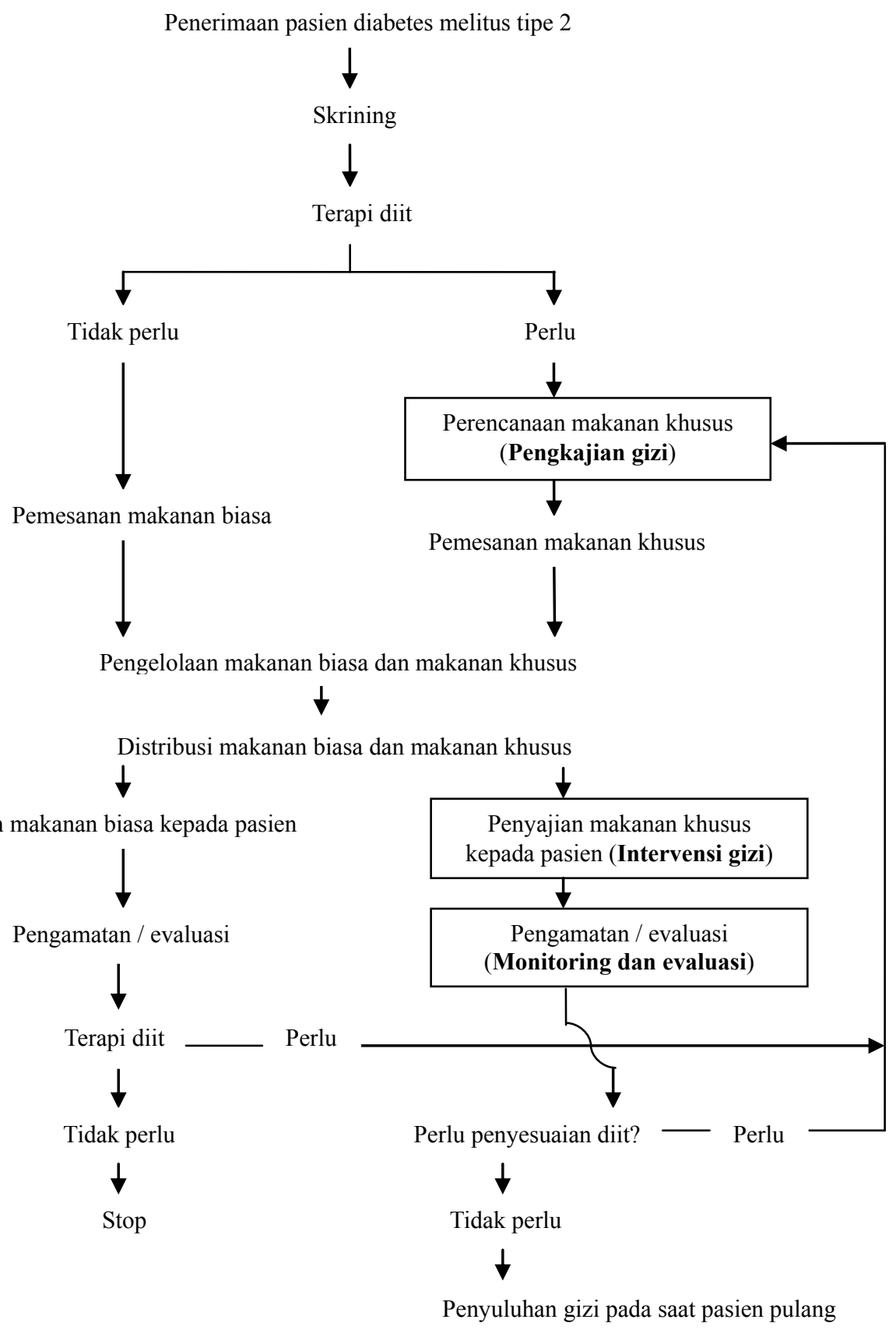

Gambar 2. Alur asuhan gizi konvensional

dilakukan berdasarkan diagnosis medis. Monitoring dan evaluasi dilakukan terhadap asupan zat gizi dan kadar glukosa darah. Alur kegiatan asuhan gizi dengan PAGT dan konvensional secara jelas ditampilkan dalam

\section{Gambar 1 dan 2.}

Pasien baru dengan diagnosis DM tipe 2 dan berumur lebih dari atau sama dengan 18 tahun pada saat penelitian diperoleh sebanyak 112 orang. Berdasarkan hasil skrining NRS-2002, sebanyak 79 orang mengalami risiko malnutrisi atau malnutrisi. Sembilan orang dikeluarkan dari penelitian karena masuk dalam kriteria eksklusi (oedema atau ascites). Jumlah subjek kelompok PAGT sebanyak 30 orang setelah drop out sebanyak 4 orang (1 orang meninggal, 2 orang kondisi menurun, dan 1 
orang pulang atas permintaan sendiri) dan pada kelompok asuhan gizi konvensional sebanyak 30 orang setelah drop out sebanyak 6 orang (1 orang meninggal, 3 orang kondisi menurun, dan 2 orang pulang atas permintaan sendiri).

Instrumen yang digunakan adalah timbangan berat badan dengan ketelitian $0,1 \mathrm{~kg}$; alat pengukur tinggi badan (microtoise) dengan ketelitian $0,1 \mathrm{~cm}$; timbangan makanan dengan ketelitian $0,1 \mathrm{~kg}$; lembar informasi responden; informed consent; formulir identitas pasien; formulir skrining gizi; formulir catatan asupan zat gizi; formulir asuhan gizi konvensional; dan formulir PAGT. Pengumpulan data primer dan sekunder dilakukan oleh peneliti dan 4 orang enumerator yang terdiri dari enumerator ahli gizi sebanyak 2 orang dan enumerator pelaksana gizi sebanyak 2 orang. Kualifikasi enumerator ahli gizi adalah pendidikan minimal DIII Gizi dan enumerator yang akan melakukan PAGT harus mempunyai sertifikat pelatihan PAGT sedangkan enumerator pelaksana gizi adalah pendidikan terakhir SMKK/SMA dan telah bekerja di bagian gizi minimal 2 tahun.

Data primer meliputi data karakteristik pasien melalui pengisian formulir identitas pasien dan wawancara, data antropometri melalui pengukuran berat badan, tinggi badan atau tinggi lutut, data asupan zat gizi di RS melalui metode penimbangan makanan (food weighing) dan wawancara, data asupan zat gizi luar RS melalui metode recall 24 jam serta data kegiatan asuhan gizi konvensional dan PAGT yang dilakukan oleh peneliti dan enumerator. Data asupan zat gizi adalah data asupan sebelum dan sesudah intervensi untuk mengetahui terjadinya peningkatan atau penurunan setelah dilakukan intervensi. Data sekunder yaitu data glukosa darah yang diperoleh dari catatan hasil laboratorium. Analisis yang lakukan pada penelitian ini adalah analisis univariat untuk mengetahui gambaran karakteristik subjek; uji normalitas data dengan menggunakan uji Shapiro-Wilk; dan analisis bivariat untuk mengetahui perbedaan asupan zat gizi dan kadar glukosa darah antara kelompok PAGT dan asuhan gizi konvensional dengan menggunakan $t$-test. Penelitian ini telah memperoleh ethical clearance dari Komisi Etik Fakultas Kedokteran Universitas Gadjah Mada.

\section{HASIL}

Berdasarkan hasil uji statistik karakteristik subjek penelitian menunjukkan bahwa tidak ada perbedaan jenis kelamin, umur, pendidikan, dan pekerjaan antara kelompok PAGT dan asuhan gizi konvensional $(\mathrm{p}>0,05)$ (Tabel 1). Sebagian besar subjek pada kedua kelompok tidak memiliki penyakit penyerta yaitu $73,3 \%$ pada

Tabel 1. Karakteristik subjek penelitian

\begin{tabular}{|c|c|c|c|c|c|c|}
\hline \multirow{3}{*}{ Karakteristik } & \multicolumn{4}{|c|}{ Jenis asuhan gizi } & \multirow{3}{*}{$\chi^{2}$} & \multirow{3}{*}{$\mathbf{p}$} \\
\hline & \multicolumn{2}{|c|}{ PAGT $(n=30)$} & \multicolumn{2}{|c|}{ Konvensional $(\mathrm{n}=\mathbf{3 0})$} & & \\
\hline & $\mathbf{n}$ & $\%$ & $\mathbf{n}$ & $\%$ & & \\
\hline \multicolumn{7}{|l|}{ Jenis kelamin } \\
\hline Laki-laki & 14 & 46,7 & 12 & 40 & 0,27 & 0,60 \\
\hline Perempuan & 16 & 53,3 & 18 & 60 & & \\
\hline \multicolumn{7}{|l|}{ Umur (tahun) } \\
\hline $18-40$ & 1 & 3,3 & 1 & 3,4 & 0,32 & 0,85 \\
\hline $41-59$ & 21 & 70 & 19 & 63,3 & & \\
\hline$\geq 60$ & 8 & 26,7 & 10 & 33,3 & & \\
\hline \multicolumn{7}{|l|}{ Pendidikan } \\
\hline SD & 0 & 0 & 0 & 0 & 1,11 & 0,29 \\
\hline SLTP & 0 & 0 & 0 & 0 & & \\
\hline SLTA & 20 & 66,7 & 16 & 33,3 & & \\
\hline Perguruan tinggi & 10 & 33,3 & 14 & 46,7 & & \\
\hline \multicolumn{7}{|l|}{ Pekerjaan } \\
\hline Tidak bekerja & 10 & 33,3 & 14 & 46,7 & 5,23 & 0,26 \\
\hline PNS/TNI/Polri & 16 & 53,4 & 14 & 46,7 & & \\
\hline Karyawan swasta & 1 & 3,3 & 1 & 3,3 & & \\
\hline Wiraswata & 3 & 10 & 1 & 3,3 & & \\
\hline
\end{tabular}

86 - Jurnal Gizi Klinik Indonesia, Vol. 10, No. 2, Oktober 2013 
Tabel 2. Hasil skrining gizi

\begin{tabular}{|c|c|c|c|c|}
\hline \multirow{3}{*}{ Karakteristik } & \multicolumn{4}{|c|}{ Jenis asuhan gizi } \\
\hline & \multicolumn{2}{|c|}{ PAGT $(n=30)$} & \multicolumn{2}{|c|}{ Konvensional $(n=30)$} \\
\hline & $\mathbf{n}$ & $\%$ & $\mathrm{n}$ & $\%$ \\
\hline \multicolumn{5}{|l|}{ IMT $<20,5 \mathrm{~kg} / \mathrm{m}^{2}$} \\
\hline $\mathrm{Ya}$ & 20 & 66,7 & 23 & 76,7 \\
\hline Tidak & 10 & 33,3 & 7 & 23,3 \\
\hline \multicolumn{5}{|l|}{ BB hilang dalam 3 bulan } \\
\hline $\mathrm{Ya}$ & 28 & 93,3 & 30 & 100 \\
\hline Tidak & 2 & 6,7 & 0 & 0 \\
\hline \multicolumn{5}{|l|}{ Asupan turun pada minggu terakhir } \\
\hline $\mathrm{Ya}$ & 22 & 73,3 & 26 & 86,7 \\
\hline Tidak & 8 & 26,7 & 4 & 13,3 \\
\hline \multicolumn{5}{|l|}{ Menderita sakit berat } \\
\hline Ya & 5 & 16,7 & 3 & 10 \\
\hline Tidak & 25 & 83,3 & 27 & 90 \\
\hline \multicolumn{5}{|l|}{ Gangguan status gizi } \\
\hline Normal & 0 & 0 & 0 & 0 \\
\hline $\begin{array}{l}\text { BB turun }>5 \% \text { dalam } 3 \text { bulan atau } \\
\text { asupan } 50-75 \%\end{array}$ & 6 & 20 & 5 & 16,7 \\
\hline $\begin{array}{l}\text { BB turun }>5 \% \text { dalam } 2 \text { bulan atau } \\
\text { IMT } 18,5-20,5 \text { atau asupan } 25-50 \%\end{array}$ & 20 & 66,7 & 23 & 76,7 \\
\hline $\begin{array}{l}\text { BB turun }>5 \% \text { dalam } 1 \text { bulan atau } \\
\text { IMT }<18,5 \text { atau asupan } 20-25 \%\end{array}$ & 4 & 13,3 & 2 & 6,7 \\
\hline
\end{tabular}

Keterangan: PAGT = proses asuhan gizi terstandar; IMT = indeks massa tubuh; $\mathrm{BB}=$ berat badan

Tabel 3. Persentase rerata asupan zat gizi

\begin{tabular}{lcccccc}
\hline \multirow{2}{*}{ Zat gizi } & \multicolumn{3}{c}{ PAGT } & \multicolumn{4}{c}{ Asuhan gizi konvensional } \\
\cline { 2 - 6 } & $\begin{array}{c}\text { Sebelum } \\
\text { intervensi (\%) }\end{array}$ & $\begin{array}{c}\text { Sesudah } \\
\text { intervensi (\%) }\end{array}$ & $\boldsymbol{\Delta}$ & $\begin{array}{c}\text { Sebelum } \\
\text { intervensi (\%) }\end{array}$ & $\begin{array}{c}\text { Sesudah } \\
\text { intervensi (\%) }\end{array}$ & $\boldsymbol{\Delta}$ \\
\hline Energi & 53,8 & 97,8 & 44,0 & 55,1 & 87,2 & 32,1 \\
Protein & 52,3 & 95,1 & 42,8 & 49,2 & 86,5 & 37,3 \\
Lemak & 65,9 & 96,6 & 30,7 & 62,8 & 88,1 & 25,3 \\
Karbohidrat & 54,2 & 94,9 & 40,7 & 60,2 & 87,3 & 27,1 \\
\hline
\end{tabular}

Keterangan: $\Delta=$ selisih; PAGT $=$ proses asuhan gizi terstandar

kelompok PAGT dan 63,3\% pada kelompok konvensional. Hasil skrining gizi NRS-2002 pada kelompok PAGT dan asuhan gizi konvensional memiliki IMT kurang dari 20,5 $\mathrm{kg} / \mathrm{m}^{2}$, berat badan hilang dalam 3 bulan, asupan turun pada minggu terakhir, dan gangguan status gizi terbanyak terdapat pada kategori penurunan berat badan lebih dari $5 \%$ dalam 2 bulan atau IMT $18,5-20,5 \mathrm{~kg} / \mathrm{m}^{2}$ atau asupan $25-50 \%$. Hal tersebut menunjukkan bahwa responden berisiko malnutrisi atau malnutrisi (Tabel 2).

Rerata kadar glukosa darah puasa sebelum dilakukan asuhan gizi lebih tinggi pada kelompok PAGT (225,5 $\pm 35,3 \mathrm{mg} / \mathrm{dL}$ vs $218,3 \pm 35,6 \mathrm{mg} / \mathrm{dL} ; \mathrm{p}=0,43)$. Namun, berdasarkan hasil uji statistik menunjukkan tidak ada perbedaan kadar glukosa darah puasa pada kedua kelompok. Data asupan gizi diambil pada hari pertama subjek masuk rumah sakit. Hal ini untuk mengetahui rerata asupan gizi pasien baru pada hari pertama dirawat sebelum dilakukan intervensi asuhan gizi (PAGT atau asuhan gizi konvensional). Rerata asupan energi selama perawatan cenderung meningkat sebesar $44 \%$ pada kelompok PAGT dan pada kelompok asuhan gizi konvensional sebesar 32,1\%. Demikian juga untuk rerata asupan protein, lemak, dan karbohidrat selama perawatan yang cenderung meningkat (Tabel 3). Berdasarkan hasil uji normalitas menunjukkan asupan zat gizi (energi, protein, lemak, dan karbohidrat) terdistribusi normal. 
Tabel 4. Persentase asupan zat gizi akhir penelitian

\begin{tabular}{|c|c|c|c|c|c|c|c|c|}
\hline \multirow{3}{*}{$\begin{array}{l}\text { Asupan zat } \\
\text { gizi (\%) }\end{array}$} & \multicolumn{6}{|c|}{ Jenis asuhan gizi } & \multirow{3}{*}{$\mathbf{t}$} & \multirow{3}{*}{$\mathbf{p}$} \\
\hline & \multicolumn{3}{|c|}{ PAGT } & \multicolumn{3}{|c|}{ Konvensional } & & \\
\hline & Rerata \pm SD & Min & Maks & Rerata \pm SD & Min & Maks & & \\
\hline Energi & $97,8 \pm 3,4$ & 91,1 & 110,1 & $87,2 \pm 5,7$ & 77,6 & 100 & 8,8 & 0,0000 \\
\hline Protein & $95,1 \pm 3,7$ & 88,2 & 100 & $86,5 \pm 7,1$ & 67,9 & 100 & 5,9 & 0,0000 \\
\hline Lemak & $95,6 \pm 3,2$ & 90,1 & 100 & $88,1 \pm 5,9$ & 80,1 & 100 & 6,1 & 0,0000 \\
\hline Karbohidrat & $94,9 \pm 3,5$ & 90,0 & 100 & $87,8 \pm 4,6$ & 80,2 & 100 & 6,8 & 0,0000 \\
\hline
\end{tabular}

Keterangan: $P A G T=$ proses asuhan gizi terstandar; $\mathrm{SD}=$ standar deviasi; $\min =$ minimal; maks $=$ maksimal

Tabel 5. Persentase asupan dari luar rumah sakit

\begin{tabular}{lcc}
\hline \multirow{2}{*}{ Asupan (\%) } & \multicolumn{2}{c}{ Jenis asuhan gizi } \\
\cline { 2 - 3 } & PAGT (n=2; 6,7\%) & Konvensional (n=6; 20\%) \\
\cline { 2 - 3 } & Rerata \pm SD & Rerata \pm SD \\
\hline Energi & $9,3 \pm 1,3$ & $21,2 \pm 0,5$ \\
Protein & $9,6 \pm 0,8$ & $20,5 \pm 1,2$ \\
Lemak & $10,2 \pm 0,1$ & $19,8 \pm 0,7$ \\
Karbohidrat & $8,5 \pm 2,1$ & $22,4 \pm 0,4$ \\
\hline
\end{tabular}

Tabel 6. Kadar glukosa darah puasa berdasarkan jenis asuhan gizi

\begin{tabular}{|c|c|c|c|c|c|c|}
\hline \multirow{2}{*}{$\begin{array}{l}\text { Jenis } \\
\text { asuhan gizi }\end{array}$} & \multicolumn{2}{|c|}{ Kadar glukosa darah puasa (mg/dL) } & \multirow[b]{2}{*}{$\Delta$} & \multirow[b]{2}{*}{$\mathbf{t}$} & \multirow[b]{2}{*}{$\mathbf{p}$} & \multirow[b]{2}{*}{$95 \% \mathrm{CI}$} \\
\hline & $\begin{array}{c}\text { Sebelum perlakuan } \\
(\text { rerata } \pm \text { SD) }\end{array}$ & $\begin{array}{c}\text { Setelah perlakuan } \\
\text { (rerata } \pm \text { SD) }\end{array}$ & & & & \\
\hline PAGT & $225,5 \pm 35,3$ & $116,1 \pm 6,9$ & $-109,4$ & 0,45 & 0,67 & $-13,8-21,8$ \\
\hline Konvensional & $218,3 \pm 35,6$ & $112,8 \pm 6,0$ & $-105,5$ & & & \\
\hline
\end{tabular}

Keterangan: PAGT=proses asuhan gizi terstandar; $\Delta=$ selisih; $\mathrm{SD}=$ standar deviasi

Hasil uji statistik terhadap asupan zat gizi meliputi energi, protein, lemak, dan karbohidrat dengan pelaksanaan PAGT dan asuhan gizi konvensional menghasilkan nilai $\mathrm{p}$ kurang dari 0,001 sehingga menunjukkan bahwa asupan energi, protein, lemak, dan karbohidrat lebih tinggi pada kelompok PAGT dibandingkan kelompok asuhan gizi konvensional (Tabel 4).

Jumlah responden dengan asupan zat gizi dari luar rumah sakit lebih banyak pada kelompok asuhan gizi konvensional yaitu sebanyak $20 \%$, artinya 6 orang subjek dari total sampel 30 orang makan makanan dari luar rumah sakit dan rerata asupan zat gizi dari luar rumah sakit terinci pada Tabel 5.

Rerata kadar glukosa darah puasa awal sebelum dilakukan asuhan gizi lebih tinggi pada kelompok PAGT. Penurunan kadar glukosa darah pada kelompok PAGT sebesar 109,4 mg/dL dan kelompok asuhan gizi konvensional sebesar 105,5 mg/dL. Selisih penurunan kadar gula darah pada kelompok PAGT dan kelompok asuhan gizi konvensional sebesar 3,9 mg/dL. Hasil analisis statistik menunjukkan bahwa penurunan kadar glukosa darah lebih tinggi pada kelompok PAGT dibandingkan kelompok asuhan gizi konvensional tetapi tidak bermakna ( $p>0,05)$ (Tabel 6).

\section{BAHASAN}

Hasil penelitian ini menunjukkan persentase rerata asupan zat gizi subjek pada awal pelaksanaan asuhan gizi sebesar 49,2\%-65,9\%. Asupan zat gizi yang kurang pada awal masuk rumah sakit dan berisiko malnutrisi atau malnutrisi bila tidak didukung asuhan gizi yang efektif dapat menjadi malnutrisi, malnutrisi berat, bahkan terjadi komplikasi penyakit atau penyakit semakin parah. Ketidakseimbangan antara asupan dan kebutuhan zat gizi karena adanya perubahan asupan gizi atau metabolik terganggu akan mengakibatkan malnutrisi (13). Konsekuensi dari malnutrisi mempengaruhi fungsi 
dan penyembuhan setiap organ yaitu perubahan berat badan akibat hilangnya massa otot dan massa tulang, diare akibat saluran cerna yang berubah, infeksi pernafasan dan infeksi bakteri atau parasit akibat imun yang terganggu, penurunan sekresi insulin, apatis, depresi, serta penurunan kapasitas fungsional dan kondisi metabolisme (14). Penelitian di beberapa rumah sakit menunjukan bahwa pada awal masuk rumah sakit, pasien malnutrisi yang menderita penyakit noninfeksi sebesar $68,57 \%$ dan asupan energi dan protein yang tidak adekuat merupakan faktor risiko malnutrisi (15). Semakin baik status gizi awal masuk rumah sakit disertai asupan energi yang cukup, semakin kecil risiko untuk pulang dalam keadaan tidak sembuh. Sebaliknya, semakin kurang status gizi awal dan asupan energinya akan berisiko lebih besar untuk pulang dalam keadaan tidak sembuh (16).

Berdasarkan hasil wawancara, subjek menyatakan bahwa kurangnya asupan zat gizi pada awal masuk rumah sakit karena kurangnya nafsu makan, kekhawatiran terhadap kenaikan kadar glukosa darah, dan pemilihan jenis makanan lauk dan sayur lebih disukai dibandingkan makanan pokok. Pemilihan jenis makanan yang tidak sesuai karena subjek tidak mengetahui makanan yang diperbolehkan, dibatasi, dan dihindari sesuai dengan penyakitnya. Salah satu upaya meningkatkan pengetahuan dan kemampuan individu atau keluarga tentang gizi dilakukan dengan edukasi gizi (7). Pengetahuan gizi yang kurang akan mempengaruhi pengaturan makan. Pengaturan makanan yang kurang baik pada penyandang DM tipe 2 akan menimbulkan gangguan kontrol metabolik yang ditunjukkan pada pengendalian glukosa, lipid, dan tekanan darah (17).

Hasil penelitian ini menunjukkan asupan zat gizi (energi, protein, lemak, karbohidrat) pada awal penelitian (awal pasien masuk rumah sakit) dikategorikan kurang (asupan $<80 \%$ ). Namun, setelah dilakukan intervensi asuhan gizi, asupan kedua kelompok mengalami peningkatan. Rerata asupan energi, protein, lemak, dan karbohidrat pada akhir penelitian lebih tinggi pada kelompok PAGT dibandingkan asuhan gizi konvensional $(p<0,001)$. Penelitian ini menunjukkan bahwa pelaksanaan PAGT dapat meningkatkan asupan zat gizi yang lebih tinggi dibandingkan dengan pelaksanaan asuhan gizi konvensional. Namun, penelitian ini tidak meneliti hubungan asupan zat gizi dengan kadar glukosa darah. Peningkatan asupan gizi lebih tinggi pada kelompok PAGT disebabkan adanya perbedaan metode pemecahan masalah terhadap asupan zat gizi. Pemecahan masalah gizi pada kelompok asuhan gizi konvensional melalui intervensi gizi, diberikan berdasarkan hasil pengkajian gizi tanpa melihat masalah gizi pada setiap individu. Berbeda dengan PAGT yang merupakan suatu metode pemecahan masalah yang sistematis yaitu dietisien profesional menggunakan cara berpikir kritisnya dalam membuat keputusan untuk menangani berbagai masalah gizi sehingga dapat memberikan asuhan gizi yang aman, efektif, dan berkualitas tinggi (7). Struktur dan kerangka konsisten yang digunakan untuk memberikan asuhan gizi dan menunjukkan bagaimana asuhan gizi tersebut dilakukan, mendukung dan mengarah pada asuhan gizi secara individual (18).

Tahapan diagnosis gizi dalam PAGT merupakan langkah memberikan nama masalah gizi menggunakan bahasa yang terstandar. Bahasa yang terstandar pada diagnosis gizi merupakan kunci penilaian klinis yang dibutuhkan untuk berkomunikasi, dokumentasi, dan mengevaluasi efektivitas asuhan gizi. Pada penelitian ini, masalah gizi dikelompokkan sesuai domain antara lain inadekuat oral intake, perubahan nilai kadar glukosa darah dan nilai laboratorium lain berkaitan dengan penyakitnya, kurangnya pengetahuan terkait gizi, pemilihan makanan yang salah, dan pola makan yang salah. Pemecahan masalah dilakukan dengan langkahlangkah yang berurutan dan saling berkaitan. Diagnosis gizi ditetapkan sebagai langkah kritis yang menjembatani antara pengkajian gizi dan intervensi gizi.

Intervensi dalam PAGT diberikan sesuai dengan akar masalah yang ditegakkan, domain intervensi meliputi pemberian makanan dan zat gizi, edukasi gizi, konseling gizi, dan koordinasi gizi (7). Asupan zat gizi yang tidak sesuai dengan kebutuhan, baik kelebihan atau kekurangan zat gizi erat kaitannya dengan peningkatan risiko penyakit maupun komplikasinya dan berdampak pada penurunan status gizi selama pasien dirawat di rumah sakit (19). Intervensi yang dilakukan adalah intervensi yang memungkinkan untuk direncanakan dan dilaksanakan. Diit dapat berubah sesuai dengan perubahan masalah gizi yang dimonitoring dan dievaluasi berkesinambungan hingga masalah gizi dapat diatasi. Besarnya asupan gizi 
makanan rumah sakit merupakan salah satu indikator keberhasilan intervensi gizi yang diberikan (20).

Penelitian ini sejalan dengan penelitian sebelumnya yang menghasilkan peningkatan persentase asupan energi dan protein sebelum dan setelah intervensi, yaitu $72 \%$ menjadi $85 \%$ untuk protein dan $85 \%$ menjadi $103 \%$ untuk energi (21). Asupan energi pada pasien DM setelah dilakukan terapi gizi medis (TGM) dan asuhan gizi konvensional menunjukkan bahwa rerata persentase asupan total rumah sakit untuk semua zat gizi pada asuhan gizi TGM dikategorikan baik dan nilai lebih besar dibandingkan asuhan gizi konvensional (22). Hasil penelitian di RSUD M.M Dunda dan RSUD Prof Dr. Aloe Saboe Gorontalo menunjukkan bahwa rerata asupan zat gizi selama pengamatan (energi, protein, lemak, dan karbohidrat) lebih baik pada asuhan gizi TGM dibandingkan konvensional dengan persentase asupan zat gizi lebih dari atau sama dengan $80 \%$ dan sisa makanan kurang dari $20 \%$ (12).

Hasil penelitian ini juga sejalan dengan penelitian di RSUP Dr. Hasan Sadikin Bandung bahwa rerata asupan energi dan protein pada pasien sesudah dilakukan PAGT masing-masing sebesar $91,54 \%$ dan $118,07 \%$ dengan peningkatan sebesar $49,08 \%$ dan $62,64 \%$ (23). Sementara itu, hasil penelitian ini menunjukkan peningkatan asupan zat gizi sebelum dan setelah intervensi PAGT yaitu energi $53,8 \%$ menjadi $97,8 \%$; protein $52,3 \%$ menjadi $95,1 \%$; lemak $65,9 \%$ menjadi $96,6 \%$; dan karbohidrat $54,2 \%$ menjadi $94,9 \%$.

Asupan dari luar rumah sakit lebih banyak pada subjek kelompok asuhan gizi konvensional yaitu sebesar $20 \%$. Persentase asupan dari luar rumah sakit yang lebih tinggi pada kelompok asuhan gizi konvensional menggambarkan kurang patuhnya pasien terhadap diit yang diberikan. Berdasarkan hasil wawancara, tingginya rerata asupan makan luar rumah sakit pada kelompok konvensional antara lain disebabkan subjek tidak mengetahui makanan yang diperbolehkan, dibatasi, dan dihindari sesuai dengan penyakitnya. Hal ini karena pada pelaksanaan asuhan gizi konvensional tidak dilakukan edukasi gizi secara rutin dari petugas gizi sehingga subjek tidak termotivasi untuk mengonsumsi makanan dari rumah sakit. Keberhasilan penyampaian konseling atau edukasi gizi yaitu pasien dapat memahami pesan yang diterima dan melaksanakannya. Pelayanan gizi melalui asuhan gizi yang efektif dapat meningkatkan asupan zat gizi sedangkan perencanaan makan yang sesuai kebutuhan bagi penyandang diabetes dan pemenuhan asupan zat gizi sesuai dengan kebutuhan gizi penting untuk upaya penyembuhan (4).

Hasil penelitian di RSUP Manado menunjukkan bahwa pasien DM rawat jalan mengalami penurunan kadar glukosa darah puasa yaitu $98,8 \%$ pada kelompok intervensi dan 48,1\% pada kelompok kontrol (24). Penerapan TGM dengan menggunakan pedoman praktik mempunyai efek terhadap penurunan kadar glukosa darah puasa pasien DM tipe 2 sebesar $20 \%$ setelah 6 bulan atau sekitar 4,4-7,8 mmol/dl (25). Sementara hasil penelitian ini menunjukan penurunan kadar glukosa kelompok PAGT sebesar 109,4 mg/dL dan pada kelompok asuhan gizi konvensional sebesar $105,5 \% \mathrm{mg} / \mathrm{dL}$ tetapi secara statistik tidak bermakna. Penatalaksanaan pada pasien DM tipe 2 rawat inap dimulai dengan edukasi tentang pengaturan makan (1). Pada pelaksanaan PAGT, edukasi lebih tersusun secara terencana dan dilakukan secara berkelanjutan dibandingkan dengan pelaksanaan asuhan gizi konvensional (7) sehingga subjek mengetahui dan memahami pengaturan makan sesuai penyakitnya dan gula darah dapat lebih terkontrol.

\section{SIMPULAN DAN SARAN}

Terdapat peningkatan asupan zat gizi pada kelompok PAGT dan kelompok asuhan gizi konvensional. Asupan zat gizi (energi, protein, lemak, dan karbohidrat) dengan pelaksanaan PAGT lebih tinggi dibandingkan dengan asuhan gizi konvensional pada pasien DM tipe 2. Penurunan kadar glukosa darah lebih besar pada pelaksanaan PAGT dibandingkan dengan asuhan gizi konvensional pada pasien DM tipe 2 tetapi secara statistik tidak bermakna.

Manajemen rumah sakit perlu melakukan pengembangan dan memberikan dukungan terhadap pelaksanaan PAGT bagi pasien DM tipe 2 di ruang rawat inap. Perlu adanya penelitian lebih lanjut tentang pengaruh pelaksanaan PAGT pada jenis penyakit lainnya dan bagi pasien diabetes perlu konsultasi gizi lanjut secara rutin dalam mengevaluasi makan dan kepatuhan terhadap pelaksanaan diitnya. 


\section{RUJUKAN}

1. PERKENI. Konsensus pengelolaan dan pencegahan diabetes melitus di Indonesia. Jakarta: Perkumpulan Endokrinologi Indonesia; 2011.

2. Depkes RI. Laporan hasil riset dasar kesehatan (Riskesdas) 2007. Jakarta: Departemen Kesehatan Republik Indonesia; 2008.

3. Syahbudin S. Diabetes melitus dan pengelolaannya. Dalam: Pedoman diet diabetes melitus. Jakarta: Balai Penerbit FKUI; 2009.

4. Dwijayanthi L. Ilmu gizi menjadi sangat mudah, nutritional made incredibly easy. ed 2. Jakarta: EGC; 2011.

5. Soegondo S. Diagnosis dan klasifikasi diabetes melitus terkini. Dalam: Penatalaksanaan diabetes melitus terpadu. Jakarta: Balai Penerbit FKUI; 2009.

6. Waspadji S. Diabetes melitus mekanisme dasar dan pengelolaannya yang rasional. Dalam: Penatalaksanaan diabetes melitus terpadu. Jakarta: Balai Penerbit FKUI; 2009.

7. Sumapradja MG, Fayakun YL, Widyastuti D. Proses asuhan gizi terstandar (PAGT). Jakarta: Abadi Publishing \& Printing; 2011.

8. Lacey K, Pritchett E. Nutrition care process and model: ADA adopt road map to quality care and outcomes management. J Am Diet Assoc 2008;103(8):348-58.

9. Siagian A. Epidemiologi gizi. Jakarta: Penerbit Erlangga; 2010.

10. Harun SR, Putra ST, Chair I, Sastoasmoro S. Uji klinis. Dalam: Dasar-dasar metodologi penelitian klinis. Jakarta: Sagung Seto; 2011.

11. Lemeshow S, Hosmer DWJr, Klar J, Lwanga. Besar sampel dalam penelitian kesehatan. Terjemahan Pramono D. Yogyakarta: Gadjah Mada University Press; 1997.

12. Pakaya AA, Wachid DN, Budiningsari RD. Pengaruh pelaksanaan asuhan gizi dengan pendekatan terapi gizi medis (TGM) terhadap intake makan dan status gizi pasien rawat Inap RSUD M.M Dunda dan RSUD Prof Dr. Aloe Saboe Gorontalo [Tesis]. Yogyakarta: Universitas Gadjah Mada; 2009.

13. Norman K, Pichard, C, Lochsa H, Pirlicha M. Prognostic impact of disease-related malnutrition. Clinical Nutrition 2008;27:5-15.
14. Saunders J, Smith T, Stroud M. Malnutrition and undernutrition. Medicine 2011;3(1):45-50.

15. Kusumayanti I, Hadi H, Susetyowati. Faktor-faktor yang mempengaruhi kejadian malnutrisi pasien dewasa di ruang rawat inap. Jurnal Gizi Klinik Indonesia 2004;1(1):9-17.

16. Syamsiatun NH, Hadi H, Julia M. Hubungan antara status gizi awal dengan status pulang dan lama rawat inap pasien dewasa di rumah sakit. Jurnal Gizi Klinik Indonesia 2004;1(1):27-32.

17. Depkes RI. Pedoman penyelenggaraan tim terapi gizi di rumah sakit. Jakarta: Depkes RI; 2009.

18. American Dietetic Association International dietetics and nutrition terminology (IDNT) reference manual: Standardized language for nutrition care process. Third edition. USA: ADA; 2011.

19. Braunschweig $C$, Gomez S, Sheean PM. Impact of decline in nutritional status of outcome in adult patient hospitalized for more than 7 days. J Am Diet Assoc 2000;100(13):131622.

20. Depkes RI. Pedoman pelayanan gizi rumah sakit. Jakarta: Depkes RI; 2003.

21. Lassen KO, Kruse F, Bjerru M, Jensen L, Hermansen K. Nutritional care of Danish medical inpatients: effect on dietary intake and dietary intake and the occupational groups perspectives of intervention. Nutrition Journal 2004;3:1-13.

22. Chasbullah IY, Gunawan IMA, Budiningsari RD. Pelaksanaan asuhan gizi dengan pendekatan terapi gizi medis (TGM) berpengaruh terhadap asupan gizi pasien di RSUD Kota Bekasi. Jurnal Gizi Klinik Indonesia 2008;5(1):1-8.

23. Fayakun YL. Peranan proses asuhan gizi terstandar terhadap asupan zat gizi, status gizi dan lama rawat inap di RSUP Dr. Hasan Sadikin Bandung tahun 2011 [Tesis]. Yogyakarta: Universitas Gadjah Mada; 2011.

24. Salman, Hadi H, Julia M. Pengaruh standar diet terhadap pengendalian glukosa darah pasien diabetes melitus tipe 2 rawat jalan di RSUP Manado. Berita Kedokteran Masyarakat 2002;XVIII(4):185-94.

25. Norris SL, Engelgau MM, Narayan KMV. Effectiveness of self management training intipe 2 diabetes. A systematic review of RCT. Diabetes Care 2001;24:561-87. 